\title{
New Subjects of Entrepreneurship in Russia - Self-Employed Persons
}

\section{Tokar Efim Yakovlevich}

High School of Management, Samara State University of Economics, Samara Region, the Russian Federation

Email address:
tokarprolex@mail.ru

\section{To cite this article:}

Tokar Efim Yakovlevich. New Subjects of Entrepreneurship in Russia - Self-Employed Persons. International Journal of Economics, Finance and Management Sciences. Vol. 8, No. 3, 2020, pp. 122-127. doi: 10.11648/j.ijefm.20200803.15

Received: May 22, 2020; Accepted: June 12, 2020; Published: June 29, 2020

\begin{abstract}
The article is dedicated to novelties in regulation of entrepreneurship in the Russian Federation, regulation of rights of individuals residing in the Russian Federation and a number of other states: Kazakhstan, Armenia, Kyrgyzstan, and Belarus, to carry out professional activities and receive incomes in the self-employed status in conditions of application of the special tax regime Tax on Professional Activities. The experiment of introducing self-employed persons started on January 1, 2019. It was conducted initially in four subjects of the Russian Federation, and then it was extended to 23 regions. Starting from July 1, 2020, it will be applied throughout the jurisdiction of the Russian Federation. The number of self-employed persons is increasing with each passing month of the experiment. In our opinion, the emergence of a new subject in addition to pre-existing legal forms of entrepreneurship (private entrepreneurs, public and non-public joint stock companies, limited liability companies, etc.) allows individuals, including citizens of a number of states, as we see, not only to raise additional income but also use their professional skills and abilities. Activities of self-employed persons cover a significant number of professions, and specialties, except for only some of them mentioned in the article. The loyal tax regime for self-employed persons will allow them to make a decision based on their will either to be employed and dependent on position, and sometimes on employer's mood or to fulfill themselves, perhaps, in danger of adequate revenue loss but with beliefs in own abilities and skills. Settling down to a course of this type of entrepreneurial activity, the market environment should be taken into account and economical segments where a service or goods produced by a self-employed person will be sold should be analyzed.
\end{abstract}

Keywords: Self-Employed, Special Tax Regime, Tax on Professional Activities

\section{Introduction}

Based on the results of the carried out research, we can state that in 2019, along with the existing forms of incorporation such as: unincorporated individual entrepreneurs (hereinafter referred to as "IE") [1], limited liability companies, public and non-public corporations (including joint-stock companies), unitary enterprises and a number of other forms, there appeared a new form of incorporation in the Russian Federation: self-employed having selected the special tax regime Tax on Professional Income ("TPI").

\section{Legitimization of the Self-employed as Subjects of Law}

The 'self-employed' term is used for the first time in regulatory acts of the Russian Federation in interstate standard (GOST) 12.0.004-2015. Clause 3.18 of the GOST gives the following definition: "a self-employed is a person rendering services on a standalone basis, under civil agreements including in the form of individual entrepreneurship". This term is used multiple times in the cited document (Articles 4.2, 4.7, 7.1, 7.2 and 13.1, 13.2, 13.9 of the GOST) [2].

Scientific discussions have touched legitimation of self-employed as subjects of law $^{1}$ [3-5]. The discussion has been centered around the analysis of their status: whether their activities are referred to entrepreneurial or so-called "other" activities of individuals carried out exclusively by their own efforts, an ability to manufacture goods and render a specific list of services on a standalone basis.

\footnotetext{
${ }^{1}$ Corresponding member of Institute of State and Law of The Russian Academy of Sciences M.I. Kleandrov has been one of the initiators of statutory regulation of the activities of self-employed.
} 
As noted by Professor I. V. Ershova, "from the economic standpoint, the activities of self-employed are at times the only or the primary source of subsistence for themselves and their families. However, such persons fail to discharge one of a handful of constitutional obligations: tax payment. From the fiscal position of the government, their activities bring a negative effect: the budget does not receive significant amounts from shadow economy each year" [6].

According to various sources, the total of 3 to 15 million persons in Russia may be working "for themselves" (i.e. without any official records) [7].

The Russian Federation (the "RF") has adopted a conceptual political and economic decision to conduct an experiment aimed at motivating individuals to come out of the shadow economy, make their income generation activities legal combined with the discharge of the obligation before the state to pay taxes to the budget.

Four administrative territorial units have been initially selected to join the experiment: Moscow, the Moscow and Kaluga regions and the Republic of Tatarstan. The experiment was launched on January 1, 2019 based on the adopted Federal Law On Conduction of an Experiment on the Establishment of a Special Tax Regime 'Tax on Professional Income' in the Federal City of Moscow, the Moscow and Kaluga Regions and the Republic of Tatarstan (Tatarstan) (the "first version of FL No. 422") [8]. The experiment will continue till 2028.

\section{The Special Tax Regime "Tax on Professional Income"}

The Law is also in effect in respect of IE who have no employees are ready to get registered as self-employed provided however that they may still be on the record with the Unified State Register of Individual Entrepreneurs (the "USRIE")

When the first version of FL No. 422 entered into force on January 1, 2019, there appeared a new subject of entrepreneurship: individuals in the self-employed status. They started to be called self-employed in the legal environment and the explanations of the Federal Tax Service of Russia (the "FTS RF") and the Ministry of Finance of the RF (the "Minfin RF")

In our opinion, the ancestors of self-employed have been individuals legitimately engaged in individual labour activities pursuant to the Law of the USSR On Individual Labour Activities adopted in 1986 (the "Law of the USSR") [9].

\footnotetext{
${ }^{2}$ See, e.g.: The Minfin Commented What Should Be Considered a Place of Business in the TPI Regime (for Rent) / Letter of the Minfin No. 03-11-11/15310 of March 11 , 2019

https://yandex.ru/turbo?utm source=turbo turbo\&text=http $\% 3 \mathrm{~A} \% 2 \mathrm{~F} \% 2 \mathrm{Frussia}-\mathrm{i}$ n-law.ru\%2Fminfin-otvetil-chto-yavlyaetsya-mestom-deyatelnosti-v-rezhime-npd -dlya-arendyi\%2F; The FTS on the Distant Place of Business of Self-Employed / Letter of the FTS of Russia No. СД-4-3/23424@ of November 18, 2019 // https://yandex.ru/turbo?utm_source=turbo_turbo\&text=http $\% 3 \mathrm{~A} \% 2 \mathrm{~F} \% 2 \mathrm{Frussia}-\mathrm{i}$ n-law.ru\%2Ffns-o-meste-vedeniya-deyatelnosti-samozanyatyimi-distantsionno $\% 2$
}

This Law of the USSR regulated the legal status of persons having come of age, able and wishing to perform individual labour activities, although "... in the time free from the main job" (Article 3 of the Law of the USSR). Such condition is easily explained: the state policy centered around combating social parasitism. The whole working-age population was obliged to work or at least be officially employed by state enterprises, institutions, organizations.

At the time of adoption, the Law of the USSR marked the beginning of socioeconomic processes in the USSR named Perestroika and in the author's opinion was the first step towards creation of the entrepreneur class [10].

By the end of the first year of the experiment a decision was made to expand both the subject composition of the experiment participants, namely individuals being residents of the Russian Federation (citizens and persons domiciling in the territory of the Russian Federation), and administrative-territorial units where this experiment will be carried out (the number of the regions was increased to 23 subjects [11]) [12] ${ }^{3}$ from the perspective of harmonizing private and public legal interests, international cooperation, solving the problem of implementing the national project named "Small and medium business and support to the individual entrepreneurial initiative" [13]. The government extended the experiment over the entire territory of the Russian Federation this April by delegating its powers related to the initiative procedure to introduce the special tax regime in units of the Federation [14].

An individual has several distant means to get registered as a self-employed: in the My Tax mobile app using a passport; in the taxpayer's account at the website of the FTS of Russia using the individual taxpayer number (INN) and the password from the individual's account at the nalog.ru website; or through the authorized bank or the Unified Portal of State and Municipal Services.

The main principle of the form of incorporation of self-employed lies in the government providing an individual with an opportunity to fulfill oneself as a subject of private law and public law relationships and at the same time acquire a set of powers:

1. To carry out legitimate activities pursuant to the All-Russian Classifier of Economic Activity Types (OKVED) [15] in one or several economy sectors including production of goods, trade, taking into account some limitations (Article 6 of FL No. 422) and a broad range of services except for the ones listed in Article 4 of FL No. 422.

2. To receive income from performed activities [16] and declare such income to the tax authority with no need to submit any documents.

3. The right of a self-employed not to carry out some

\footnotetext{
${ }^{3}$ Individuals being residents of the states of the former Soviet Union, which are now the member states of the Eurasian Economic Union (EEU): Kazakhstan, Armenia, Kyrgyzstan, and Belarus (Article 5 of Federal Law No. 422), which are ready to carry out entrepreneurial activity under the experiment conditions as self-employed entities in the territory of the Russian Federation as defined in Federal Law No. 422, may be become new business entities.
} 
actions such as opening of a separate account with a bank institution for professional activities or use of cash register equipment (CRE) is viewed as manifestation of loyalty towards a new subject of entrepreneurship.

Needless to say, that an obligation of the new subject of entrepreneurship is compliance with the instruction to pay taxes within the framework of the special tax regime TPI.

It is stipulated that a self-employed will pay the following taxes instead of the usually applied personal income tax rate of $13 \%$ :

- 4\% of incomes received from individual clients;

- $6 \%$ of incomes received from legal entities or IE (Article 10 of FL No. 422).

The regulatory function of the state has also appeared in limitation of the upper limit of income received by a self-employed: 2.4 million rubles per annum (Subclause 8 Clause 2 Article 4 of FL No. 422). The monthly income amount is not limited.

The imperative obligation of entrepreneurs to maintain accounting records, get registered with the compulsory medical insurance fund, the Pension Fund of the RF, bear public obligations to pay other taxes and duties stipulated in other forms of incorporation is not applied in the studied form of entrepreneurship.

There exists a number of peculiarities that although cannot be referred to negative ones still need to be understood by persons wishing to acquire the self-employed status.

Making this decision, an individual needs to understand that the period of activities as such subject of entrepreneurship will not be taken into account in calculation of the work experience and thus will not affect the pension assignment procedure or the pension amount. The self-employed status does not stipulate any obligatory contributions towards the pension insurance purposes, although a solution exists. A self-employed may on a voluntary basis enter into an agreement with one of private pension funds. The right to a social pension is not forfeited ${ }^{4}$.

The legislator has determined the obligation to produce goods and render services professionally, on a standalone basis, personally (the term "on a standalone basis" is contained only in subordinate acts - explanations of the FTS $\mathrm{RF}$ ) as one of the fundamental conditions for a person to be acknowledged self-employed and thus qualified for preferences for this category of persons along with fulfillment of the imperative state requirement not to have employees.

It appears that the criterion of "professionalism" declared in the name of the taxation system applied to self-employed is more associated with an acceptable form of perception of activities of individuals a priori meaning the versatility of professions the subjects of entrepreneurship having the self-employed status can be involved in as well as sound quality of rendered services and produced goods.

Representatives of the state (meaning primarily authorized

\footnotetext{
4 See: Articles 12, 12. 1 Of Federal Law No. 178-FZ of July 17, 1999 On State Social Assistance // Corpus of Legislative Acts of the RF. July 19, 1999. No. 29. Article 3699.
}

government bodies: the FTS RF, the Ministry of Finance of the RF (the "Minfin RF")) will not request self-employed to submit any diplomas, graduation certificates, certificates of industry-specific education or certificates of proficiency. Although such documents can be requested, for example, by a judicial authority ${ }^{5}$ or the client consuming such services. Well, it is his right, because it is the consumer who will select the corresponding self-employed as a professional in the specific sphere or as a goods manufacturer.

It is relevant to use the self-employed status while carrying out the activities of pastry chefs, hairdressers, babysitters, private tutors, cleaning, repair, construction workers, privately practicing lawyers, specialists in economy, bookkeeping, etc. Marketing experts can consult on a distant basis, the same applies to design of logistics schemes or business project development. Communication means and electronic sites (platforms) facilitate rendering of such services.

Some limitations by activity types are set.

The state has used the instrument of imperative instructions to prohibit lawyers, mediators, official receivers, notaries (Subclause 12 Clause 2 Article 6 of FL No. 422) representatives of the legal community, professionals whose activities are subject to licensing or accreditation from operating as self-employed. Medical workers ${ }^{6}$ and auditors ${ }^{7}$ will not be able to become TPI subjects either. FL No. 422 contains an exhaustive list of taxation objects not falling under the TPI (Article 6 of FL No. 422).

IEs will also be able to use the preferential tax treatment and receive the self-employed status (Articles 2, 4 of FL No. 422). In this case, their legal status seems dual: they have a right to remain in the USRIE and at the same time can express the desire to select the TPI system and get included in the self-employed entrepreneur category following a notification and registration procedure.

IEs will be able to replace the existing entrepreneurship status (form of incorporation) with a more economically advantageous if they:

1) Sell goods that are self-produced only.

2) Perform works and render services without any employees.

3) Observe the general conditions for self-employed concerning the total income per calendar year: RUB 2.4 m (Article 6 of FL No. 422).

\footnotetext{
5 Since October 1, 2019 acting as a representative in courts of the Russian Federation requires obligatory submission of a diploma of legal education. See: Parts 1, 2 Article 49 of the Civil Procedure Code of the Russian Federation No. 138-FZ of November 14, 2002 № 138-Ф3 // Corpus of Legislative Acts of the RF. November 18, 2002. No. 46. Article 4532; Parts 3, 6 Article 59 of the Arbitration Procedure Code of the Russian Federation No. 95-FZ of July 24, 2002 // Corpus of Legislative Acts of the RF. July 29, 2002. No. 30. Article 3012; Part 1 Article 55 of the Code of Administrative Proceedings of the Russian Federation No. 21-FZ of March 8, 2015 // Corpus of Legislative Acts of the RF. March 9, 2015. No. 10. Article 1391.

${ }^{6}$ See: Subclauses 46-47 Clause 1 Article 12 of Federal Law No. 99-FZ of May 4, 2011 On Licensing of Some Activity Types // Corpus of Legislative Acts of the RF. May 9, 2011. No. 19. Article 2716.

7 See: Clause 1 Article 11 of Federal Law No. 307-FZ of December 30, 2008 On Auditing Activities // Corpus of Legislative Acts of the RF. January 5, 2009. No. 1. Article 15.
} 
Only if all of these conditions are observed, an IE may use the special tax regime TPI (as opposed to the simplified taxation system ${ }^{8}$ generally accepted for this incorporation form of entrepreneurship).

What is the mechanism of cooperation between corporations, other forms of legal entities, IEs with self-employed? Is it beneficial to establish such cooperation, build relationships with self-employed?

A priori, judging by the principle of good faith of taxpaying companies ready to drop sketchy schemes with envelope salaries, such companies may legally enter into civil agreements with the required specialists whose prior official status has been "employee" (the relationships have been built based on provisions of labour laws - the Labour Code of the RF [17]) as self-employed.

Legal minimization of taxation is obvious. A legal entity or an IE has to pay to the budget of a constituent entity of the federation (in conditions of labour relationships) income tax in the amount of $13 \%$ of the official incomes of an employee, $2.9 \%$ to the social insurance fund, $22 \%$ to the pension fund and $5.1 \%$ to the obligatory medical insurance fund [18]. However, a legal entity or an IE will not be bearing this tax burden within the framework of civil relationships with a self-employed.

Legal entities (corporations, IEs, unitary enterprises, etc.) entering into civil relationships with self-employed will be able to legally minimize their tax base by recognizing as costs (deduct from the tax base) any expenses borne to pay for the services or independently produced goods of new subjects of entrepreneurship ${ }^{9}$.

\section{Doctrinal Position}

The following doctrinal position may be proposed based on the results of the carried out research.

1) As a result of adoption and entry into legal force of FL No. 422, there has been legitimated ${ }^{10}$ a new subject of entrepreneurship nominated by the state as a self-employed - a competent individual under the laws of the Russian state, being a resident of the Russian Federation (we assume that this may include persons without citizenship or having a residence permit) and other states taking part in the experiment, producing and selling goods (self-produced only) on a standalone basis

\footnotetext{
${ }^{8}$ See: Chapter 26.2 of the Tax Code of the Russian Federation (Part Two) No. 117-FZ of August 5, 2000 // Corpus of Legislative Acts of the RF. August 7, 2000. No. 32. Article 3340.

${ }^{9}$ See: Subclause 41 Clause 1 Article 264 of the Tax Code of the RF (Part One) No. 146-FZ of July 31, 1998 // Corpus of Legislative Acts of the RF. No. 31. August 3, 1998. Article 3824

${ }^{10}$ This position is also reflected in: Legal Business Navigator on Small and Medium-Sized Entrepreneurship: monograph. Op. cit. P. 53-55; Ershova I.V. Self-Employment: The First Steps in Establishment of the Legal Regime (edited by Doctor of Law S.D. Mogilevskiy and Doctor of Law M.A. Egorova) // Russian Presidential Academy of National Economy and Public Administration. Law Faculty named after M.M. Speranskiy of the Institute of Law and National Security. - Justice Inform, 2017. P. 191-200; Ershova I.V., Trofimova E.V. Self-Employment: Reference Points of Establishment of the Legal Regime // Entrepreneurial Law. 2017. No. 3. P. 3-12.
}

and rendering services using his/her professional skills, without any employees, considering the limitations stipulated by Articles 4, 6 of FL No. 422, to individuals and legal entities of any legally consolidated form of incorporation, individual entrepreneurs based on civil agreements concluded orally, in writing or otherwise, provided that such individual follows the notification and registration procedure to receive the self-employed status and complies with the imperative instruction of the state: to pay Tax on Professional Income pursuant to the special tax regime.

2) It may be stated that entrepreneurial activities of the new subject are carried out in the following form of incorporation: self-employed having selected the special tax regime TPI.

3) In spite of the fact that the legal status of self-employed is still neither defined not regulated in the federal laws $[19,20]$, although there has been an attempt to word its legitimate definition in a bill prepared by the Ministry of Justice of Russia (the "Minjus RF") on May 29, 2018 [21], one still can conclude that the existing institutional provisions are indirectly pointing at the fact that the activities of self-employed are entrepreneurial considering their content.

Two factors strengthen the author's position about reference of self-employed to subjects of entrepreneurship: 1) the dominant idea is the indisputable fact that a self-employed is operating at his/her sole risk in order to generate profit (income (the author's commentary)), which is an attribute of entrepreneurship ${ }^{11}$ and 2) the right to become a self-employed may be exercised by individual entrepreneurs, who a priori are subjects of entrepreneurship.

1) Attention should be focused on the fact that an individual claiming the self-employed status declares his/her "professionalism" and consumers of the goods produced by him/her and proposed services along with the state a priori believe that he/she possesses the indicated subjective attribute.

2) The will of an individual capable to work is manifested in his/her own paradigm, mental model that leads him/her to self-employed by providing a legitimate opportunity to generate income from entrepreneurial activities, have a financial source of satisfying personal and family demands in combination with the obligation to pay tax to the state.

The will, permissions of the state act in our opinion as a regulated offer proposed to a wide range of people (society members) able to accept it on suitable and beneficial conditions satisfying inter alia public interests.

6. It may be admitted that a self-employed can receive income from legitimate activities at the participation and with the help of family members although there is no direct indication thereto in the adopted statutory acts and regulations governing the self-employed status (explanations of the FTS

\footnotetext{
${ }^{11}$ See: Article 2 of the Civil Code of the Russian Federation.
} 
RF, the Minfin RF, etc.) ${ }^{12}$. We assume that it is not obligatory for them to undergo the registration procedure. Firstly, this is driven by moral and ethical principles of the patriarchal character of the society; secondly, by economic efficiency considerations; thirdly, the state hardly needs to meddle with positive relationships within a family; fourthly, it is practically impossible to determine the share of a family member's involvement in the activities of a self-employed. By the way, the earlier cited Law of the USSR had a provision containing a permission to carry out individual labour activities “... together with family members living in the same household (spouse, parents and other relatives and dependents having reached the age of 16)" (Article 3 of the Law of the USSR).

7. It seems that from the doctrinal standpoint, the self-employed category can become a harmonious constituent of companies based on kinship relationships. Some relatives will make an active nucleus aimed at creation of tangible values (financial benefit, means for existence), fulfillment of entrepreneurial tasks. The other part considering the age, capabilities, education, may work as self-employed make in their turn a contribution to achieve the tasks based on family business. They may be relatives (family members) with the self-employed status working for consideration as babysitters, private tutors, housekeepers, stewards, teachers, drivers, etc. The legal relationships with this group will be built based on the legal algorithm described earlier with the right to minimize the cost thanks to taxation benefits for self-employed.

8. Self-employed have no obligation to make mandatory insurance contributions to the pension fund, although there remains an opportunity to make such payments on a voluntary basis by selecting any private pension fund. At the same time, they may count on minimum pension payments. As there is no obligation to make contributions to the obligatory medical insurance fund, self-employed can enter into a voluntary medical insurance agreement.

9. In the meantime, FL No. 422 does not prohibit self-employed to be in labour relationships with any companies, legal entities or IE (acting as employers). However, the received salary will not fall under the TPI. Salary incomes will be subject to the generally accepted $13 \%$ tax. In this case, work experience is recorded for the pension assignment purposes $^{13}$.

10. The existing approach of the law enforcement authorities qualifying the income generation activities of individuals as illegal entrepreneurship ${ }^{14}$ can be repudiated by

\footnotetext{
${ }^{12}$ It should be noted that there is no statutory definition of "family" in Russian laws. Blood relatives and the ones acquired through marriage and other legal acts may be referred to family members.

13 The incomes are acknowledged an special tax regime TPI object if the client was an employer of the indicated individual more than two years ago. See: Subclause 8 Clause 2 Article 6 of FL No. 422.

14 Such offence entails administrative liability under Article 14.1 of the Administrative Offence Code of the Russian Federation No. 195-FZ of December 30, 2001 // Corpus of Legislative Acts of the RF. 2002, No. 1 (Part 1). Article 1; and criminal liability: on a large scale - pursuant to Part 1 Article 171 of the Criminal Code of the Russian Federation No. 63-FZ of June 13, 1996 // Corpus of Legislative Acts of the RF. 1996. No. 25. Article 2954 (the "CC RF"); on an especially large scale - pursuant to Part 2 Article 171 of the CC RF.
}

positive actions of persons claiming the self-employed status. Attention should also be focused on negative consequences of carrying out of entrepreneurial activities without due registration and fulfillment of the procedures stipulated by the imperative instructions of the state, e.g., licensing of some activity types [22].

We have to refer the following to the number of lacunae (from Latin lacuna, gaps) in legal regulation of activities of self-employed as subjects of entrepreneurship:

1) The self-employed term is used in informal explanations and recommendations of the FTS RF and the Minfin RF. The Civil, Tax Codes of the RF and other laws have not regulated this term yet.

2) FL No. 422 has no definition of the concept of "place of business" of a self-employed. At present, one should be guided only by the developing law enforcement practice, explanations of the FTS of Russia and the Minfin RF. The place of business may be the location (place of residence, registration) of a self-employed or the place of fulfillment of a civil agreement concluded orally or usually in writing and with the help of digital technologies with an individual, a legal entity or an IE or the location of the client (goods, service consumer) obviously in the region taking place in the experiment.

3) The issue of the property liability of the new subject of entrepreneurship for obligations arising out of civil relationships aimed at generation of income from professional activities still remains unsolved on the legal level. Similarly to the liability of IEs, the property liability of self-employed will be obviously limited to foreclosure on all property they own (Article 24 of the CC RF).

4) The law has also not determined the bankruptcy procedure if it is caused by entrepreneurial activities of a self-employed. In our opinion, it is justified to apply the rules stipulated by $\$ 2$ Chapter X of the Federal Law On Insolvency (Bankruptcy) (the "FL On Bankruptcy") [23] if a self-employed is also registered as an individual entrepreneur. However, if a self-employed has not been primarily registered as an IE, individual bankruptcy peculiarities are likely to be applied ( $\$ 1$ Chapter X of FL On Bankruptcy). We believe that since self-employed enter the number of subjects of entrepreneurship, the bankruptcy procedure should be governed by the rules of $\S 2$ Chapter X of FL On Bankruptcy unless the legislator develops any separate rules (procedures) or gives corresponding explanations in regulations.

\section{Conclusion}

As in any experiment, the practice may a priori reveal other law enforcement gaps. Thus, e.g., state declaration of non-documentary confirmation of incomes by a self-employed may lead to closer attention of the FTS RF, law enforcement authorities to contractors buying goods produced by self-employed or receiving services from self-employed. Otherwise, fiscal authorities will not be able to control compliance of a self-employed with the obligatory criteria of 
this status. The criterion of "professionalism" will most likely be referred to the number of optional ones.

Time as an objective criterion of any experiment will surely show the efficiency of the proposed instrument for involvement of citizens capable to work in the legal field as self-employed.

Thus, e.g., the pilot project Small and Medium-Sized Entrepreneurship and Support of the Individual Entrepreneurial Initiative [24] launched in the Samara region on January 1, 2020 has already produced results: about 4 thousand people got registered as self-employed during the first month [7], of the end of February $2020-7,4$ thousand people.

The performance practice, number of registered persons will further determine whether the experiment of the public government is successful. Much will also depend on the mentality of the population capable to work.

\section{References}

[1] Federal Law No. 129-FZ of August 8, 2001 On State Registration of Legal Entities and Individual Entrepreneurs // Corpus of Legislative Acts of the RF. August 13, 2001. No. 33 (part I). Article 3431.

[2] GOST 12.0.004-2015. Interstate Standard. Occupational Safety Standards System. Occupational Safety Training Organization. General Provisions. // Official Documents in Education. No. 36. December. 2016.

[3] Kleandrov M. I. On the Need for Acquisition of a Legal Status by an Unregistered Entrepreneur// Entrepreneurial Law. 2015. No. 3. P. $9,12$.

[4] The VII all-Russian scientific and practical conference Law and Business. The Legal Business Environment: Integration of Science, Education, Practice. Kutafin University (MSAL). Moscow. June 1, 2018.

[5] Scientific and practical conference: Russian Entrepreneurial Law: Results, Tendencies and Development Paths. Law Faculty of the Lomonosov MSU. Moscow. June 4, 2019.

[6] Legal Business Navigator on Small and Medium-Sized Entrepreneurship: monograph / publishing editor I. V. Ershova. - Moscow: Prospect, 2018. P. 48.

[7] Ozerov L. Four Thousand People Have Acknowledged Themselves Self-Employed. // Samara Overview. No. 3 (1722). February 3, 2020. P. 11.

[8] Federal Law No. 422-FZ of November 27, 2018 On Conduction of an Experiment on the Establishment of a Special Tax Regime 'Tax on Professional Income' in the Federal City of Moscow, the Moscow and Kaluga Regions and the Republic of Tatarstan (Tatarstan) // Corpus of Legislative Acts of the RF. 2018. No. 49 (part I). Article 7494.

[9] Law of the USSR On Individual Labour Activities // News of the Supreme Soviet of the USSR. 1986. No. 47. Article 964 (ceased to be in force on April 4, 1991).

[10] Tokar E. Ya. Legal and Economic Aspects of Activities of Subjects of Entrepreneurship: Legal Novelties and Application Practice. Samara: BOOK PUBLISHING HOUSE, LLC. 2018. P. 9-10.
[11] Federal Law No. 422-FZ of November 27, 2018 On Conduction of an Experiment on the Establishment of a Special Tax Regime 'Tax on Professional Income' // Corpus of Legislative Acts of the RF. December 3, 2018. No. 49 (part I). Article 7494.

[12] Passport of the national project Small and Medium-Sized Entrepreneurship and Support of the Individual Entrepreneurial Initiative (approved by the Presidium of the Presidential Council for Strategic Development and National Projects (Minutes No. 16 of December 24, 2018)) // https://base.garant.ru/72185938/

[13] Federal Law No. 428-FZ of December 15, 2019 On Amendment of Federal Law On Conduction of an Experiment on the Establishment of a Special Tax Regime 'Tax on Professional Income' in the Federal City of Moscow, the Moscow and Kaluga Regions and the Republic of Tatarstan (Tatarstan) // Corpus of Legislative Acts of the RF. December 16, 2019. No. 50. Article 7201.

[14] The Federal Law "On the amendments to Article 1 of the Federal Law "On carrying out the experiment to set the special tax regime "Earned income tax" dated 01.04.2020 No. 101-Ф3// RG. No. 72. 03.04.2020.

[15] Regulation of the Social Insurance Fund of the RF On Approval of the Key Ratios by Economic Activity Types for 2020 No. 64 of May 23, 2019 (registered by the Minjus of Russia under No. 55485 of August 2, 2019) // Official internet portal of legal information. http://www.pravo.gov.ru, August 5, 2019.

[16] Tokar E. Ya. Representation in Entrepreneurial Activities: Legal Regulation and Law Enforcement Issues: thesis of ... Doctor of Law / E. Ya. Tokar. Moscow, 2018. P. 268.

[17] Labour Code of the Russian Federation No. 197-FZ of December 30, $2001 / /$ Corpus of Legislative Acts of the RF. January 7, 2002. No. 1 (part 1). Article 3.

[18] Galimullina N. Self-Employed Will Be Tended to // Samara Overview. No. 11 (1685). 2019. P. 14.

[19] Civil Code of the Russian Federation (Part One) No. 51-FZ of November 30, 1994 // Corpus of Legislative Acts of the RF. December 5, 1994. No. 32. Article 3301.

[20] Tax Code of the Russian Federation (Part One) No. 146-FZ of July 31, 1998 // Corpus of Legislative Acts of the RF. No. 31. August 3, 1998. Article 3824.

[21] Bill of the Federal Law On the Amendment of Some Legal Acts of the Russian Federation Concerning Determination of the Self-Employed Status (prepared by the Minjus of Russia on May 29, 2018) // https://base.garant.ru/56753994/

[22] Federal Law No. 99-FZ of May 4, 2011 On Licensing of Some Activity Types // Corpus of Legislative Acts of the RF. May 9, 2011. No. 19. Article 2716.

[23] Federal Law No. 127-FZ of October 26, 2002 On Insolvency (Bankruptcy) // Corpus of Legislative Acts of the RF. October 28, 2002. No. 43. Article 4190.

[24] A Pilot Project Creating Special Tax Terms for Self-Employed Is Being Launched in the Samara Region // https://www.samregion.ru/press_center/news/v-samarskoj-obl asti-startuet-pilotnyj-proekt-po-sozdaniyu-osobyh-nalogovyhuslovij-dlya-samozanyatyh-grazhdan/ 